\title{
The Use of Fractional Cards for Fraction Learning in The Fifth Grade Students of Elementary School
}

\author{
Ari Indriani \\ Department of Mathematics Education, IKIP PGRI Bojonegoro \\ Corresponding author: ariindrianiemail@gmail.com
}

\begin{abstract}
This research aims to investigate the use of fractional cards on teaching in the fifth grade students of Elementary School. The method used is descriptive qualitative. The researcher used observation, interview, and documentation to collect the data. The results showed that there was an increase on the students' enthusiasm for learning process, and there were 27 students (69.23\%) that have a score above the Minimum Criteria of Mastery (Kriteria Ketuntasan Minimal/KKM). The study concludes that the use of fractional cards able to help the learning process on the fractions material of the fifth grade students of Elementary School.
\end{abstract}

Keywords: fractional cards, elementary school, fraction

Abstrak. Tujuan penelitian ini adalah untuk mendeskripsikan penggunaan kartu pecahan pada pembelajaran materi pecahan serta dampaknya pada siswa kelas V Sekolah Dasar. Metode yang digunakan dalam penelitian ini adalah deskriptif kualitatif. Teknik pengumpulan data yang digunakan adalah observasi, wawancara, dan dokumentasi. Teknike analisis data dengan metode alur yaitu reduksi data, penyajian data, dan penarikan kesimpulan. Hasil penelitian menunjukkan bahwa siswa antusias dalam pembelajaran materi pecahan dengan menggunakan media kartu pecahan. Selain itu penggunaan kartu pecahan juga berdampak. pada hasil belajar yang memuaskan yaitu ada 27 siswa (69,23\%) yang mempunyai nilai di atas KKM. Dengan demikian dapat disimpulkan bahwa penggunaan kartu pecahan pada materi pecahan dapat membantu proses pembelajaran materi pecahan pada siswa kelas V Sekolah Dasar.

Kata kunci: alat peraga kartu, pecahan, sekolah dasar

\section{Introduction}

Mathematics is an important lesson and a foundation for other lessons. This lesson is one field of study that is taught starting from elementary school to higher education level. This shows the importance of mathematics for our lives. The main purpose of mathematics as it is mandated in the curriculum is for the mathematics learning management at school to be meaningful and it could encourage the students to apply their mathematical knowledge in their daily lives and in other aspects of life. Mathematics learning is also expected to make the students more skillful in solving problems that they will encounter, both in mathematics and in other fields. Furthermore, mathematics 
learning is expected to improve the students' logical thinking ability; therefore, they would be able to think critically, logically, systematically, and in the end, students are demanded to be objective, honest, and discipline.

However, mathematics learning commonly serves as delivery of information without involving students for them to be able to understand the lesson by themselves. This is according to Silver's explanation in Yeni (2013: 2) that it is commonly found in mathematics learning, the students pay attention to the teacher who demonstrate the solution of mathematical question in the blackboard and the students imitate the solution made by the teacher. The students' habit of imitating the teacher becomes a problem when the students encounter another problem that has not been taught by the teacher. Furthermore, the teacher seldom uses teaching aids or props in explaining the lesson materials, for example fractions material.

Related to Piaget's cognitive theory in Desmita (2009: 104), the mind of elementary school students is in the phase of concrete operational thought, which is a phase where children's mental activity focuses on concrete objects or on events they have experienced. According to Piaget, operation is logical relationships between concepts or schemes. Meanwhile, concrete operational is mental activity that focuses on concrete or real objects or events that could be measured. Therefore, elementary school students will be able to understand mathematics lesson more quickly if they use mathematics aids or props (real props).

According to Sitanggang (2013), mathematics props are sets of concrete props which are intentionally made, designed, gathered or collected that are usually used to help understand or improve the concepts or principles in mathematics. On the other hand, Estiningsih in Sukayati and Suharjana (2009) explains that props are learning media consisting of or including of the characteristics of the concept being studied. Based on the definition by some experts, it can be concluded that learning props are an object or a set of concrete objects owning the characteristics of concept being studied. The use of learning props can help the students in understanding abstract object that could be represented in the form of models; therefore, the students are able to manipulate the objects by seeing, touching, groping, or turning upside down for them to understand mathematics more easily.

Elly in Sitanggang (2013) states that the functions of mathematics aids are to: 1) provide motivation for students; 2) introduce, restore, and improve the definition of concept and fact; 3) simplify the abstraction for students; 4) provide a variation for learning so that the students are not bored with the given theory; 5) ensure time efficiency in teaching because the students will be able to understand the lesson more quickly; 6) develop a topic for learning; and 7) support mathematics outside the class to show the application of mathematics in real life situation.

Furthermore, there are certain requirements that should be paid attention in making lesson props as it is explained by Ruseffendi (in Sukayati and Suharjana, 2009), such as: 1) made according to mathematical concepts; 2) could help explain the concept of mathematics, both in real object, picture or diagram; not the other way around (complicate the understanding of mathematical concepts); 3) should be durable (made from relatively strong and resilient materials); 4) made in interesting shapes and colors; 5) made from materials that are safe to be used for children's health; 6) simple and easy to manage; 7) the shape are according to or proportional to the students' physical measurement; 8) the props are expected to be the foundation for the growth of the concept of abstract thinking for the students because the props can be manipulated (could be touched, groped, paired, etc.) so that the students can actively learn both 
individually or in groups; and 9) if possible, the props should be beneficial for other purposes.

Fractions material is one of materials that cannot be easily understood by elementary school students. For example, in arithmetic operations, elementary school students are accustomed in using integrals instead of fractions, where the students face difficulty in imagining how much these fractions are. However, fractions material is being learned starting from the third grade of elementary school by introducing fractions along with the operation of addition and subtraction of fractions. On the other hand, the fractions material on the fifth grade is about fractions with similar value, for example $\frac{2}{4}=\frac{1}{2}$.

From the interview conducted with a teacher of fifth grade of elementary school, it can be concluded that the majority of students face difficulty in simplifying fractions. The difficulty in simplifying fractions is also discovered by Brown and Quinn (2006) in their research that analyzed the students' difficulty faced in fractions material. In their research that was conducted to 143 senior high school students, it was found that $27 \%$ of students could not simply fractions. Furthermore, approximately $66 \%$ students could not solve fractions in word problems form. Fazio and Segler (2011) mention three misconceptions commonly faced by the students in solving fractions. They are: 1) the students do not consider numerator and denominator as unified number; 2) they do not multiply denominator in multiplication operation; and 3) they misunderstand mixed fraction. The previous studies have shown that students still face difficulties in understanding the concept and calculating fraction numbers. Therefore, this research uses learning props in the form of fractional cards to help the learning process of fractions material.

Studies regarding the use of learning aids on fractions material have been conducted by some researchers. Nugraheni, Usada, and Kamsiyati (2013) in their research on the use fractional cards media for fractions material conclude that fractional cards could be used to improve mathematics learning outcome of the third grade students of Sekolah Dasar Negeri (Public Elementary School) 1 Mento, Wonogiri. In another research conducted by Iman (2013), he also concludes that the planning, implementation, and use of fractional cards on mathematics learning for fifth grade students of Sekolah Dasar Negeri 05 Manis Mata Kabupaten Ketapang could significantly improve the students' learning ability. Both researches show that the use of learning aids, especially fractional cards, in learning process could ultimately improve the students' learning outcome on fractions material.

This research focuses on the use of fractional cards in learning fractions material for the fifth grade elementary school students. Furthermore, this research will also describe the implementation impact of fractional cards for learning process in class. Therefore, this research aims to describe the use of fractional cards for the learning of fractions material and its impacts for the students' learning process in class.

\section{Research Methods}

This research was accomplished by using qualitative approach and was analyzed descriptively. This research was conducted at Sekolah Dasar Negeri 3 Kunduran Blora; and the research subjects were 36 students of the fifth grade. In qualitative research, the researcher played an important role because the researcher served as the main instrument as well as the data collector and the one who observed or conducted direct research at SD Negeri 3 Kunduran Blora. The data used were from direct observation result, interview, and documentation, which were classified as qualitative data. The data were then interpreted and connected to the quantitative data (test) used as the basis to describe 
the successful use of fractional cards. The data acquired from test were classified as quantitative data that were later calculated for their percentage for certain value.

The data validity was conducted through:

1. Persistent observation or full observation

This activity was conducted on the observation process in the field to find the characteristics and elements in situation that was relevant with the researched problem.

2. Peer review

Peer review was review conducted by other colleagues who possessed particular general knowledge, in this case the fifth grade teacher of SD Negeri 3 Kunduran Blora.

\section{Results and Discussion}

Before conducting the research, the author did observation to the research objects. The initial observation result conducted by the researcher by joining the learning process in class found that:

1. The fifth grade students had low mathematic learning outcome

2. The students had low enthusiasm in following the lesson because they considered mathematics as difficult subject

3. The presentation of material done by the teacher was less interesting and clear due to limitations props or media in learning used by the teacher to support the material

4. For fractions material, most students still faced some difficulties.

Based on the observation, the researcher planned and designed a learning process where the teacher used learning aids that had never been applied to fractions material. By applying fractional cards, it was expected to create learning process with variation and would be less boring. Moreover, it was expected that it would also rouse the students' enthusiasm in learning mathematics; therefore, there would be improvements in students' learning outcome, especially in fractions material.

In learning preparation activity, the researcher prepared the learning aids that would be used, which were fractional cards. The fractional cards were made looking like domino card, and how to play the fractional cards was also similar to the rules for domino card. Firstly, the researcher presented fractions material, then she used the fractional cards when the lesson reached fractions with similar value, such as $\frac{2}{4}=\frac{1}{2}$. The sample form of fractional cards used for teaching the material was presented in the following figure.
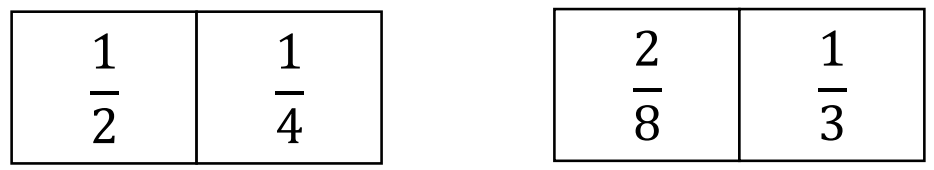

\section{Figure 1. Example of Fractional Cards}

In learning process by using fractional cards, it was initiated by categorizing students in class into some groups consisting of four to five students. After that, each group was given a set of fractional cards that would be used to practice the game of fractional cards. The way of playing fractional cards was similar to how to play domino cards. In this game, the cards were shuffled then they were distributed to every student in the groups; each student would get five or six cards. Then, the fractional cards were given to each student in the groups. Next, the teacher (or researcher) flipped open one 
card from the remaining cards. Alternately, each student continued the order of card, for example the opened card was continued by fractional card with similar value. The winner was the student with no cards on his or her hands or the student with the least number of cards on his or her hands. The implementation of learning process by using fractional cards was presented in Figure 2.
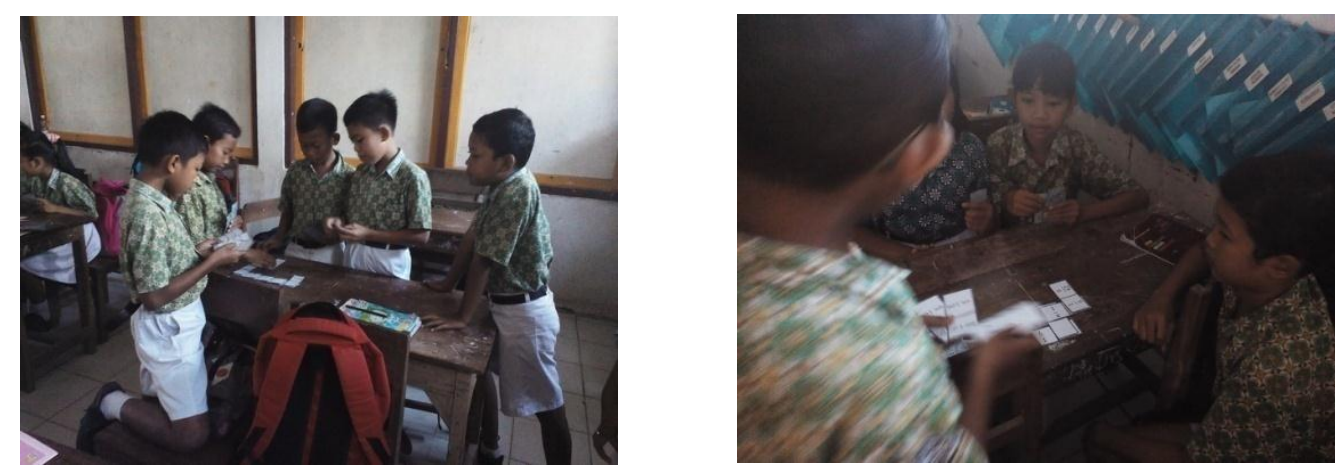

Figure 2. Learning Process by Using Fractional Cards

During playing fractional cards activity, the researcher observed the activities done by the students in the learning process. Based on the observation, it was found that the students were more enthusiastic and interested in following the lesson of fractions material; the students were not bored during the learning process because they were studying while playing; and the students were curious about the fractional cards.

After conducting an interview with the teacher, the researcher found that the fractional cards were proven useful in explaining fractions material, the class condition was quieter and more conducive, and there was no sleepy student. On the other hand, the students admitted that studying by using learning aids was more fun and it was easier for them to understand and comprehend the material. After the learning process was concluded, the researcher gave some tests to discover the students' ability in understanding fractions material that they had been taught. The tests were in multiple choices and there were ten questions (Appendix A). The students' score for the test was provided in the following Table:

Table 1. The Students' Score

\begin{tabular}{cccccccc}
\hline No & Score & Frequency & Percentage & No & Score & Frequency & Percentage \\
\hline 1 & 10 & 1 & $2.6 \%$ & 6 & 60 & 4 & $10.3 \%$ \\
\hline 2 & 20 & 2 & $5.1 \%$ & 7 & 70 & 6 & $15.4 \%$ \\
\hline 3 & 30 & 2 & $5.1 \%$ & 8 & 80 & 7 & $17.9 \%$ \\
\hline 4 & 40 & 1 & $2.6 \%$ & 9 & 90 & 5 & $12.8 \%$ \\
\hline 5 & 50 & 2 & $5.1 \%$ & 10 & 100 & 9 & $23.1 \%$ \\
\hline & & & & Total & 39 & $100 \%$ \\
\hline
\end{tabular}

Based on the data on Table 1, it could be seen that the students who acquired score above the Minimum Criteria of Mastery (Kriteria Ketuntasan Minimal/KKM) (Score $\geq$ $65)$ were 27 students $(69.23 \%)$. On the other hand, there were 12 students $(30.77 \%)$ who scored lower than KKM (Score < 65). This meant that almost $70 \%$ of students had successfully understood fractions material well. In other words, the students were able to follow the learning process by using fractional cards as learning media for fractions 
material. Meanwhile, for the students who still scored lower than KKM, generally they still encountered difficulties in receiving or understanding fractions material and some of them did not concentrate on the lesson during learning process. Based on the interview conducted to some students who scored lower than KKM, they still could not use the fractional cards well and they believed that they were not given enough time to solve the fractional questions (the time given to students to solve the test was 30 minutes).

After conducting an assessment of the students' ability with a test, the researcher re-evaluated the method by conducting question and answer with the students, especially with those who score higher than KKM. This activity aimed to acquire a benchmark for the students' achievement result. This was conducted in order to provide better understanding for the students regarding the materials they had learned. The students who score higher than KKM were given more questions to be solved in front of the class. This was also done to discover the level of honesty from the students in solving the questions, because it was possible that some students who scored higher than KKM cheated in finishing their tests. From the interview conducted with the students who scored higher than KKM, it was found that studying by using learning aids significantly help them in understanding the material they were taught and some of them asked for fractional cards to be used for studying at home.

Based on the research result, it could be concluded that the use of fractional cards could help the students in understanding fractions material. This would also bring positive impacts on students for their learning process such as better understanding of fractions concept. The research results also showed similar result to studies conducted by Nugraheni, Usada, and Kamsiyati (2013) and Iman (2013) who concluded that the use of fractional cards as learning media could improve the students' learning outcome for fractions material. Therefore, this research could provide additional evidence for the benefits of using fractional cards in learning mathematics especially for fractions material.

According to Piaget's cognitive theory, elementary school students are in concrete operational thought phase, in which the students will be quicker to understand the learned material if the learning aids used for the learning process are real objects. In this research, the learning aids used were fractional cards. By using learning aids in the form of fractional cards, the students were more enthusiastic in following the learning process, it would be easier for them to understand the lesson, and the students' learning outcome was satisfactory as well, $69.23 \%$ students scored higher than the Minimum Criteria of Mastery (Kriteria Ketuntasan Minimal/KKM). The use of fractional cards also facilitated the teachers in delivering fractions material.

Based on the research result, it was expected that elementary school teachers will be able to use learning aids in delivering their materials, especially for mathematics subject. Therefore, it would be easier for the students to understand the subject and it would facilitate the teacher to deliver their teaching materials. For example in explaining geometry, the teacher prepares learning aids or learning tools in the form of cubes, blocks, and so on; as for materials of number addition, the teacher could use number lines or make cards marked with positive and negative sign.

\section{Conclusion}

Based on the research result, it could be concluded that the use of fractional cards for fractions material on the fifth grade students of elementary school could help the learning process. This was seen through the students' enthusiasm in following the lesson; the students were not bored during the learning process because they were studying while playing; and it could also rouse their curiosity about fractional cards. Furthermore, if seen through the students' understanding ability on fractions material, there were 27 
students (69.23\%) whose mathematics score were over Minimum Criteria of Mastery (Kriteria Ketuntasan Minimal/KKM).

\section{Bibliography}

Desmita. (2009). Psikologi Perkembangan Peserta Didik. Bandung: Remaja Rosdakarya.

Fazio, Lisa. \& Siegler, Robert. (2011). Teaching Fractions. International Bureau of Accessed from http://unesdoc.unesco.org/images/0021/002127/212781e.pdf

George Brown and Robert J Quinn. (2006). Algebra Students Difficulty With Fractions An Error Analysis. Amt, 62 (4).

Iman, A. (2013). Peningkatan Hasil Belajar Siswa Dengan Menggunakan Kartu Pecahan Pada Pembelajaran Matematika. Jurnal Pendidikan dan pembelajaran, 2(7).

Nugraheni, Denik. Usada, Kasmiyati, Siti. (2013). Penggunaan Media Kartu Pecahan Untuk Meningkatkan Hasil Belajar Matematika Konsep Pecahan. Jurnal Didaktika Dwija Indria, 2(4).

Posumah, Yeni. (2013). Deskripsi Kemampuan Siswa Menentukan Hasil Perkalian Pecahan Di SDN 5 Telaga Kabupaten Gorontalo. Jurnal Penelitian Deskriptif.

Sitanggang, A. (2013). Alat Peraga Matematika Sederhana Untuk Sekolah Dasar. Medan: Lembaga Penjaminan Mutu Pendidikan (LPMP) Sumatra Utara.

Sukayati dan Suharjana, A. (2009). Pemanfaatan Alat Peraga Matematika Dalam Pembelajaran Di SD. Yogyakarta: Pusat Pengembangan dan Pemberdayaan Pendidik dan Tenaga Kependidikan (PPPPTK) Matematika. 


\section{Appendix}

Cross a, b, c, or $\mathrm{d}$ that you seem correct.

1. The simple form of $\frac{5}{15}$ is ...
a. $\frac{1}{5}$
b. $\frac{1}{4}$
c. $\frac{1}{3}$
d. $\frac{1}{2}$

2. Choose the most appropriate answer on the following question $\frac{2}{4} \ldots \frac{1}{2}$
a. $>$ b. $=$
c. $<$
d. $\geq$

3. Choose the most appropriate answer on the following question $\frac{1}{5} \ldots \frac{1}{2}$

a. $>$ b. $=$ c. $<$ d. $\geq$

4. Mother has an apple, then she distributes it to her three children. How many parts does each child get?
a. $\frac{1}{4}$
b. $\frac{1}{2}$
c. $\frac{2}{3}$
d. $\frac{1}{3}$

5. Choose the most appropriate answer on the following question $\frac{1}{3} \ldots \frac{1}{4}$
a.
b. $=$ c. $<$ d. $\geq$

6. The simple form of $\frac{2}{6}$ is ...
a. $\frac{1}{3}$
b. $\frac{1}{2}$
c. $\frac{1}{4}$
d. $\frac{1}{6}$

7. Find the result of $\frac{2}{4}+\frac{1}{3}=\cdots$
a. $\frac{4}{5}$
b. $\frac{3}{7}$
c. $\frac{5}{6}$
d. $\frac{7}{3}$

8. Find the result of $\frac{3}{6}-\frac{1}{4}=\cdots$
a. $\frac{1}{4}$
b. $\frac{2}{6}$
c. $\frac{2}{2}$
d. $\frac{2}{4}$

9. Mother buys $\frac{1}{4} \mathrm{~kg}$ of sugar; she then buy another $\frac{4}{8} \mathrm{~kg}$ of sugar. How many $\mathrm{kg}$ of sugar Mother owns now?
a. $\frac{1}{2}$
b. $\frac{5}{8}$
c. $\frac{3}{4}$
d. $\frac{4}{4}$

10. Find the result of $\left(\frac{4}{8}+\frac{1}{4}\right)-\frac{1}{3}=\cdots$
a. $\frac{1}{4}$
b. $\frac{5}{12}$
c. $\frac{6}{12}$
d. $\frac{1}{3}$ 